\title{
Development of Intraspinal Ectopic Endometrial Tissue in Connection with Tethered Cord Syndrome
}

\author{
Ling-ling Cui ${ }^{1}$, Ji-bin $\mathrm{Cao}^{1}$, Guo-guang $\mathrm{Fan}^{1}$, Xu-yong $\mathrm{Lin}^{2}$ and $\mathrm{Ke} \mathrm{Xu}{ }^{1}$
}

\begin{abstract}
We herein report a rare case of intraspinal ectopic endometrial tissue associated with tethered cord syndrome. The patient underwent MR imaging of the lumbar spine and CT spinal angiography. Asymptomatic dysraphism was also detected, including spinal bifida, low-lying conus medullaris, spinal meningocele and a lumbosacral lipoma. Venous reflux obstruction was also suggested. The patient underwent L2-S1 laminectomy and microdecompression of the lesion. The histological and immunohistochemical features were characteristic of ectopic endometrial tissue. Since the surgery, no neurological signs have been noted, either during or outside the patient's menstrual periods. The two-month follow-up MRI scans showed a regression of the lesion.
\end{abstract}

Key words: endometriosis, tethered cord syndrome, spinal canal

(Intern Med 53: 2741-2743, 2014)

(DOI: 10.2169/internalmedicine.53.2266)

\section{Introduction}

Intraspinal ectopic endometrial tissue is extremely rare. In other previously reported cases (1-4), the ectopic endometrial tissue in the spinal canal was either isolated from or associated with dysraphism. In the present case, the ectopic tissue was associated with a tethered cord, and venous reflux obstruction was suggested.

\section{Case Report}

A 50-year-old woman presented with progressive pain in the lumbosacral region radiating to both lower limbs. Initially, the pain appeared during the patient's menstrual period; however, the monthly rhythm eventually disappeared and the pain became continuous. The lower muscle strength in the extremities was diminished, and she sometimes experienced slight urine and fecal incontinence. MR imaging of the lumbar spine revealed low-lying conus medullaris ending opposite to L3. An intraspinal lipoma was detected in a thickened filum terminale at a height opposite to L3-5. Probable spinal meningocele was noted through L4-5. A soft tissue mass within the spinal canal adhered to the inferior surface of the lipoma and meningomyelocele (Fig. 1A-C). CT spinal angiography showed tortuous and thickened blood vessels (Fig. 1D). The patient underwent laminectomy of $\mathrm{L}$ 2-S1, which showed spinal bifida in L4-5, the lamina of which was found to be absent. The lipoma was densely adhesive with the cord tissue and nerve. The conus medullaris was distended, and spinal meningocele was noted under the lipoma extending through L4-5. We removed the lipoma and area of myelomeningocele, and a chocolate-colored mass subsequently became visible below the lipoma. The lesion was densely adhesive with the site of myelomeningocele and lipoma. The whole mass was then removed, and the vascular tension obviously decreased. The histological examination (Fig. 2) showed that the main tissue mass consisted of smooth muscle within which endometrial glands and stroma were present. Immunohistochemistry for estrogen receptor (ER), CD10 and cytokeratin (CK) was carried out, which showed a positive expression for all markers. The twomonth follow-up MRI scans showed regression of the lesion (Fig. 3).

${ }^{1}$ Department of Radiology, The First Hospital of China Medical University, China and ${ }^{2}$ Department of Pathology, The First Hospital of China Medical University, China

Received for publication December 13, 2013; Accepted for publication May 12, 2014

Correspondence to Dr. Ke Xu, xukecjr@163.com 

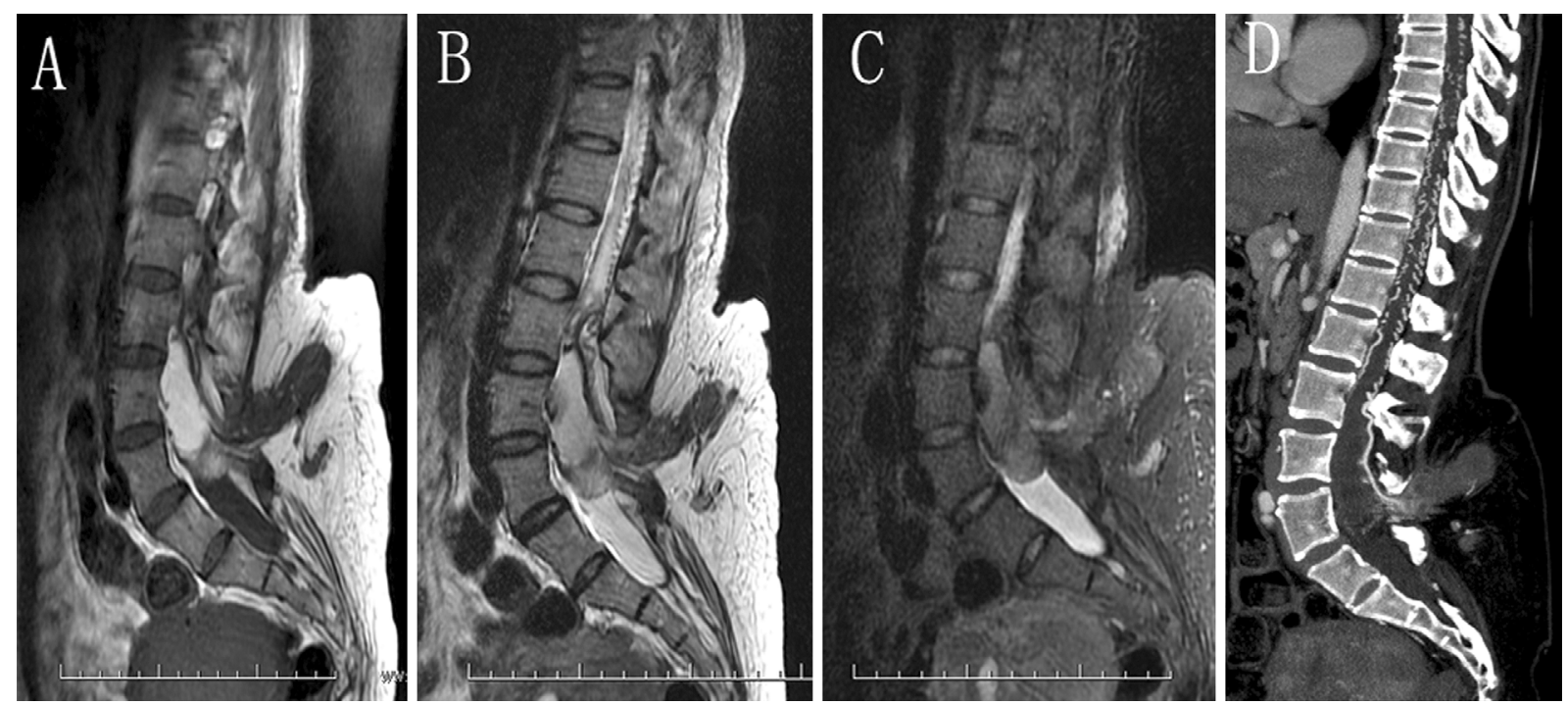

Figure 1. Sagittal magnetic resonance images of the lumbar spine. The low-lying cord ends opposite to L3. A high-signal intraspinal lipoma and probable spinal meningocele can be seen at the height of the L3-5 level. The lamina of L4-5 was found to be incomplete. A soft tissue mass within the spinal canal adhered to the inferior surface of the lipoma and site of meningocele at the $\mathrm{L} 4$ level, showing a hyperintense signal on T1-weighted sagittal MRI (A) and T2-weighted sagittal MRI (B), with a decreased signal on a STIR T2-weighted image (C). CT spinal angiography. Tortuous and thickened blood vessels within the spinal canal suggested venous reflux obstruction (D).
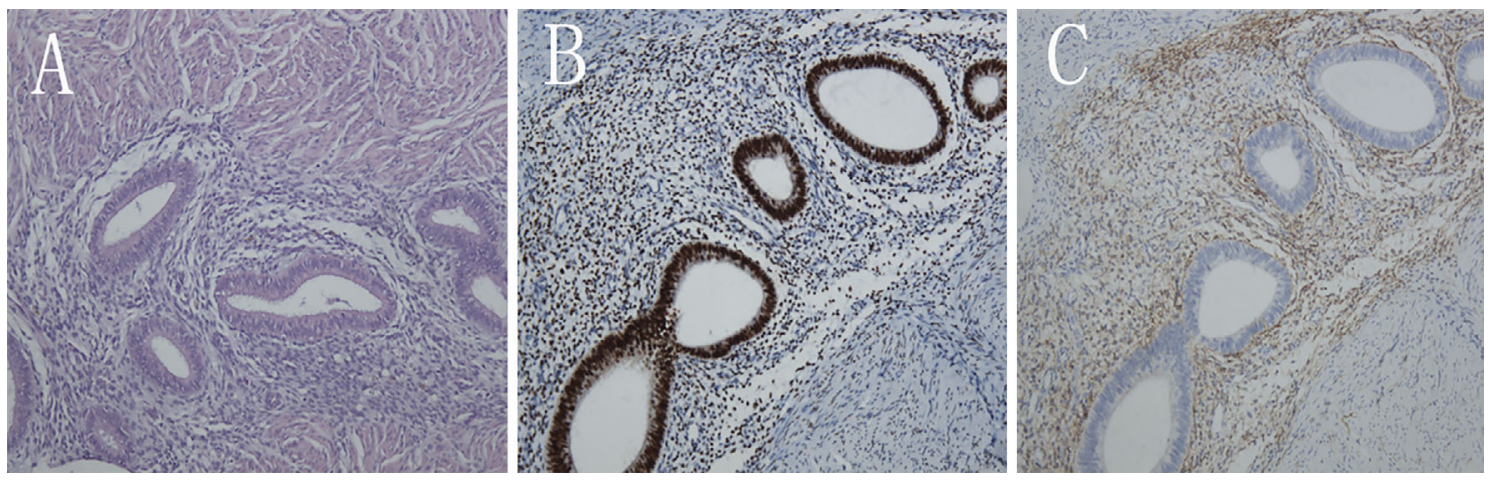

Figure 2. Histological section showing multifocal distribution of endometrial glands and stroma surrounded by smooth muscle, $\times 10$ (A). Immunoperoxidase staining for estrogen receptors, which were found to be expressed in both the endometrial glands and stromal cells, $\times 10$ (B). CD10 immunohistochemical staining highlights the endometrial stromal cells, $\times 10$ (C).

\section{Discussion}

In this case, a pathological examination disclosed that the mass was an endometrial lesion. To the best of our knowledge, some cases of intraspinal ectopic endometrium without spinal dysraphism have been reported (5-10). The present case differs from the previous cases in that both tethered cord syndrome and venous reflux obstruction were detected. The association of this type of lesion with spinal dysraphism suggests a similar pathogenesis to that of ontogenic disorders.

In our case, we believe that the patient's symptoms were connected with her menstrual period, being caused by the extravasation of blood in ectopic locations. Subsequently, the symptoms became continuous after which clot organization led to the formation of a tumor-like mass that permanently compressed the dural sac.

Various types of ectopic formation in the spinal canal have been reported, including renal tissue (11) and neurenteric cysts (12). This type of lesion is characterized by the presence of normal tissue at inappropriate locations, usually termed heterotopia. We also use the term choristoma, although this word is has only been used to describe ectopic tissue of Mullerian origin to date $(1,4)$.

The embryological origin of ectopic endometrial tissue associated with spinal dysraphism can be explained by the specific formation of the lumbosacral spinal canal. The teth- 


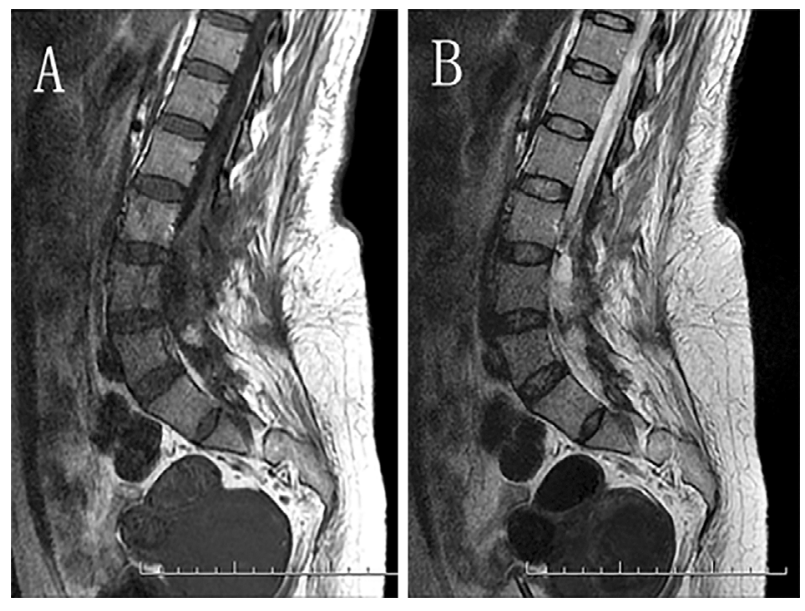

Figure 3. Follow-up T2-weighted MRI scans showing regression in the size of the lesion (compared with Fig. 1)

ered cord originates in an incomplete regressive process. Simple misplacement of Mullerian duct tissue, presumably of trunk-tail node origin, within the secondary neural tube constitutes one hypothesis (3). Alternatively, these abnormalities of the neuraxis may be epiphenomena, produced by either induction or reaction of the developing conus with heterotopic tissue of atypical germ-layer lineage (4). The persistence of portions of ectopic or accessory neurenteric canals has been reported to account for a variety of dysraphic conditions, including neurenteric fistulas and cysts, diastematomyelia, dermal sinus tracts and intraspinal lipomas (13). Another explanation is that the appearance of paramesonephric duct tissue in the spinal cord involves the dorsal translocation of early paracoelomic tissue through the notochord and ventral neural plate, akin to the development of a split cord malformation (14).

Mullerianosis is a term used to describe lesions composed of the admixture of two or three types of Mullerianderivation glands, such as endocervical, endometrial and tubal glands, at heterotopic sites (15). Because our patient had only endometrial tissue, it is difficult to justify the use of the term intraspinal Mullerianosis. Despite decades of research, the pathogenesis of endometriosis remains poorly understood. However, the potential for endometriosis in this case can be discussed, as the condition is defined as the ectopic growth of functional endometrial tissue (16).

When ectopic endometrial tissue involving the nervous system exhibits expansion, surgical removal is necessary. The presence of intraspinal ectopic endometrium must be recognized as a potential cause of periodic neurological signs and symptoms in young and middle-aged women. Timely intervention and appropriate management in patients with neurological symptoms allow for disease control and may lead to improvements in various neurological functions.

The authors state that they have no Conflict of Interest (COI).

\section{References}

1. Kurman RJ, Funk RL, Kirshenbau AH. Spina bifida with associated choristoma of Müllerian origin. J Pathol 99: 324-327, 1969.

2. Young JR, Feder JM. Ectopic endometrial tissue occurring in connection with lipoma and spina bifida occulta. South Med J 32: 1044-1046, 1939.

3. Rougier A, Vital C, Caillaud P. Uterus-like mass of the conus medullaris with associated tethered cord. Neurosurgery 33: 328-331, 1993.

4. Molleston MC, Toth KA, Wippold FJ, et al. Tethered cord syndrome from a choristoma of Müllerian origin. J Neurosurg 74: 497-500, 1991.

5. Barresi V, Cerasoli S, Vitarelli E, et al. Spinal intradural mullerianosis: A case report. Histol Histopathol 21: 1111-1114, 2006.

6. Duke R, Fawcett P, Booth J. Recurrent subarachnoid hemorrhage due to endometriosis. Neurology 45: 1000-1002, 1995.

7. Qu LM, Zhao DX, Zhong YP, et al. Endometriosis of spinal canal with vertebral involvement: report of a case. Zhonghua Bing Li Xue Za Zhi (Chinese Journal of Pathology) 40: 846-847, 2011 (in Chinese).

8. Sun Z, Wang Y, Zhao L, et al. Intraspinal endometriosis: a case report. Chin Med J (Engl) 115: 622-623, 2002.

9. Carta F, Guiducci G, Fulcheri E, et al. Radicular compression by extradural spinal endometriosis. Case report. Acta Neurochir (Wien) 114: 68-71, 1992.

10. Agrawal A, Shetty BJ, Makannavar JH, et al. Intramedullary endometriosis of the conus medullaris: case report. Neurosurgery 59: 428, 2006.

11. Erşahin Y. Split cord malformation associated with ectopic renal tissue. Childs Nerv Syst 18: 201, 2002.

12. Okechi H, Albright AL, Nzioka A. Tethered cord syndrome secondary to the unusual constellation of a split cord malformation, lumbar myelomeningocele, and coexisting neurenteric cyst. Case Report. Neurol Med 2012: 635029, 2012.

13. Lew SM, Kothbauer KF. Tethered cord syndrome: an updated review. Pediatr Neurosurg 43: 236-248, 2007.

14. Pang D, Dias M, Abdab-Barmada M. Split cord malformation: Part 1: A unified theory of embryogenesis for double spinal cord malformations. Neurosurgery 31: 451-480, 1992.

15. Batt RE, Smith RA, Buck Louis GM, et al. Mullerianosis. Histol Histopathol 22: 1161-1166, 2007.

16. Vinatier D, Orazi G, Cosson M, et al. Theories of endometriosis. Eur J Obstet Gynecol Reprod Biol 96: 21-34, 2001.

(C) 2014 The Japanese Society of Internal Medicine

http://www.naika.or.jp/imonline/index.html 